\title{
SHIFTS IN MEANING: AN EXPLORATION OFTHE TRADITIONAL ART OF IFUGAO AS CULTURAL CAPITAL IN THE FIELDS
}

\author{
Danim R. Majerano \\ Kapitolyo High School, San Ignacio St. Kapitolyo, \\ Pasig City, NCR Philippines \\ (danimmajerano@gmail.com)
}

\begin{abstract}
This paper explores how the concept of cultural capital by Pierre Bourdieu can help explain the changes in meanings of the traditional art of the Ifugao people, in the context of Wow Philippines, a project by the Philippine government. By the use of primary literature on the Ifugao community, supported by an in-depth interview with a key informant plus participant observation, this study unveils the reality of the cultural process that is being constructed, posited, and esteemed by different events, encounters, needs and exchanges. In general, traditional art has its signifying meaning and specific context enhanced through the dynamic characteristics of culture.
\end{abstract}

Keywords: Ifugao traditional art, cultural capital, acculturation, Wow Philippines

\section{Introduction}

Woven bags, abaca slippers, bead necklaces, and bracelets are considered nowadays as fashionable items. While walking along the AS (Arts and Sciences) walk, we can see booths selling these products. SM Malls are now selling cultural products inside their department stores. Whenever our parents, relatives or friends go to Vigan, Cebu or Baguio, they always return home with pasalubong (souvenir) such as bags, guitar and wallets from these places. Such exposure gave us an assumption that each of us has the passion to 
or at least, own some of any cultural products produced by the different cultural communities in the country. These products are distinct from one another in terms of the materials used, form, style and process of creation.

Meanwhile, the project of former Tourism Secretary Richard Gordon, the WOW Philippines, gave an idea to study the meanings behind the cultural goods that the different cultural groups in the Philippines produced. WOW Philippines, when it was still in its peak of flourishes, paraded the diversity of culture of the country. A particular region is assigned every month and is given a chance to display their culture. WOW Philippines also serves as a mechanism for image-formation for various cultural communities.

In line with this, some data on how cultural products are appropriated as the cultural capital of cultural groups in the WOW Philippines will be presented. It also wants to show how these products elicit information about the preferences or the way of living of such group. This research aims to focus on the occurrence of shifts in the meaning of these cultural goods and their representation of Philippine culture in WOW Philippines. To have a closer look, the details of the interview made with an Ifugao woman, who at the same time is a seller of their cultural products from Ifugao, is presented in this paper.

Pierre Bourdieu's concept of cultural capital served as my guide throughout the study. According to Bourdieu, cultural capital concerns forms of cultural knowledge, which equips the social agent towards an appreciation for competence in deciphering cultural relations and cultural artefacts. Cultural capital is measured in the number of accumulated products you own such as books, credentials, artworks, etc. Bourdieu presented a powerful model, which attempts to address issues such as how meanings and values of works are authorised and sustained into the multiple complexes of historically constituted social relations (Bourdieu, 1984, pp. 228-230).

This research used a qualitative research methodology in gathering firsthand data. A Large part of this is conversed with the informant and had a casual ad hoc observation in knowing the perceptions of people. This was employed to lessen the power relations between the informant and the researcher. Furthermore, an interview with the key informant was conducted to help with the aspects of this research. With the permission granted, she allowed stating her name throughout this paper. She is Aling Mildred, a 46year-old and a native of Banaue, Ifugao. She belongs to the cultural groups of Ifugao (mother side) and Bontok (father side). She is a Catholic but still 
practices rituals when the need arises. Her family of procreation now resides in Baguio. She has two daughters, both in their secondary schooling.

This endeavor made with the idea that the WOW Philippines is still in its prosperity. When I went in Intramuros, I was shocked to see that the place looked desolate. The clamshell, as the Philippine Tourism Authority calls it, was temporarily closed in preparation for the Flower Festival. Only four (4) booths outside the clamshell are opened. Because I do not want to change my topic, I still pursued this research and did some variations. Instead of studying various cultural products, I focused my research on the cultural products produced by the Ifugaos due to accessibility. I derived my analyses from the narratives and meanings placed by the key informant about her experiences in selling in WOW Philippines and University of the Philippines. I also utilised any literature I could find to substantiate this paper. Anthropological principles were also used in analysing emic and etic perspectives (Chambers, 1989; Emener \& Darrow, 1991). My analyses will only be true for the data gathered.

\section{The Ifugaos}

The Ifugaos are the group of people living in the Ifugao province located in the Central Cordillera Mountains of Northern Luzon. The geographic location of the Ifugao province is instrumental in the cultural group's development of their culture and beliefs. The province is the host to the famous rice terraces or payoh (Veneracion et. al., 2005), which had been inscribed on UNESCO's World Heritage List in 1995 as "a continuing cultural landscape." Colonialism brought many changes into the life of the Ifugaos. Although they resisted against the subjugation of the Spanish governance and continued to rebel against the maltreatment of the Spanish soldiers, the presence of the Americans greatly challenged their way of life. The practice of headhunting had been prohibited. It was the Americans who introduced public education and by 1950's laws were reinforced making elementary education compulsory (Andres, 2004). Education had reinforced the switch of religions of this cultural group. Although most of them had converted to Christianity, they still call their local priest or mumbaki to perform cultural ceremonies known as baki in times of sickness or emergency in the family (Andres, 2004). The economy of Ifugao is sustained predominantly from agriculture. They work in either their small rice fields or the kaingin. Educational opportunities for the Ifugaos had 
been increasing since educational institutions in the different levels are established.

\section{Their Traditional Art as Their Cultural Goods}

As mentioned earlier, my study focused on Ifugao's products particularly woodcarvings and handed woven materials. Traditional art is those woodcarvings, which include statues, furniture, and wooden utensils. Mrs Mildred classified these woodcarvings into two-decorative and nondecorative. Decorative products include statues like the bulol and the chair hagabi. She stressed that these products are mass-produced. Non-decorative products are those, which serve a specific utility. These comprise the rice bowl, wine bowl, wooden spoon, and fork.

When I asked her, the meanings behind these products in their specific context, Mrs Mildred, narrated to me how the bulol served in their rituals. "Ano kase yun... sacred sa amin. Kase during rituals nilalabas yun. Tapos pinapaliguan ng dugo tsaka ano yun blood ng baboy or chicken, tapos rice wine."(All of those are sacred to us because we used it during rituals. Then the blood of pig or chicken is being stained, together with rice wine). Bulol, the Ifugao rice god, is one of the most common and traditional ritual figures in Ifugao culture. It is stylised sculpture representation of a human figure in narra wood used in rituals associated with many stages of rice planting, healing of the sick and intergroup feuds. A consecrated bulol is bathed with pig's blood, which is believed to assume new powers and will grant the owner's wealth and prosperity. They are placed in a granary house or house attic where they are believed to make the rice grains multiply and guard the harvest from parasites and thieves. The hagabi, a huge long bench carved out of one single piece of wood whose seat arises in the in the middle from their end is considered as an ultimate status symbol. It is a sign of prestige and a proof of the owner's economic and political powers.

Hand woven materials include blankets and clothing. Mrs. Mildred classified two types of weaving -back strap weaving and handle. "Iba yung back strap weaving, iba yung tillar na hand and feet. Yung back strap weaving kamay lang tapos yung parang nakatali ka. Ang pinag-gagawan nyan under ng bahay, ng native house." (Back strap weaving is different; it has supports for hands and feet. Hands are operating the back strap weaving and as like as 
you are being laced. This is being practised under the native house). The Ifugao women weave to cater for their family's needs. Weaving also has its ritual significance - it is the invocation of a deity, Punholda'yan.

The cultural products describe earlier is a reaffirmation of Pierre Bourdieu's concept of cultural capital. According to him, cultural capital can exist in two forms-the embodied state and the objectified state. In the embodied state, it is in the form of long-lasting dispositions of the mind that presupposes embodiment (Bourdieu, 1984, p. 113). When I asked Mrs Mildred who are the people behind these carvings, he identified them as the "katutubos" or "natives." "Yung taga-roon sa amin, yung katutubo... Ifugao nakatira sa mountain." "Actually, mula bata pa sila, alam na nilang magcarve..." (All of them are natives. Ifugaos are living in the upland area., very since as a small, they know how to do woodcarving). It is evident that cultural capital is accumulated through hereditary transmission of cultural knowledge. It implies a labour of inculcation, personal costs and time invested personally by the carver in order to learn the art of carving. It also entails sacrifice. As Mrs Mildred said, some children of the 'katutubo' do not attend school anymore. It is a manifestation of the sacrifices made by these children in order to contribute something to their families. The accumulation period, according to Bourdieu, covers the whole process of socialisation. Thus, when parents inculcate this form of knowledge to their young, an acquisition of a habitus happens. A habitus is the set of dispositions in which we carry in our heads because of our social experiences in certain backgrounds and circumstances (Bourdieu, 1984, p. 114). It is a key to reproduction in order to generate the regular practices that will make up our social life. A habitus is a person's totality (Bourdieu, 1984, p. 170).

Cultural capital in its objectified state can only be defined with its relationship in its embodied form. Without cultural knowledge, cultural capital will remain in its embodied state. Thus, the objectified cultural capital is the product of cultural knowledge learned in the process if socialisation (Bourdieu 1984:105). For the Ifugao, their objectified cultural capital exists in the form of cultural goods such as the hagabi, bulol, blankets and clothing. To make a hagabi or a blanket, an Ifugao must have the cultural knowledge about its process of 'creation'. Without the embodied state, cultural goods cannot exist. Thus, to appropriate cultural capital or use it for their specific purpose, an individual must have access to embodied cultural capital.

The production of cultural capital takes place in a field (Bourdieu, 1984, p. 228). A field is a social arena in which social interaction and 
manoeuvres take place and specific resources or stakes and access to them. For the Ifugao carvers, their field of production is the community to which they belong. It is the place where they learn the knowledge in carving and weaving.

\section{Shifts in Meanings: From Sacred to Commodity}

Because of their contacts with outside influences wherein they were exposed to different types of the culture of other nations, the Ifugao's way of living changed. The colonisers attempted to enforce their culture to the Ifugao culture. We found two types of acculturation, which caused the shifts in meanings of the Ifugao cultural goods, especially those of religious icons. As what Fr. Lambrecht (1979) said, the Ifugao culture is not a heap of lifeless items, but an integrated closely linked with their religion. It is not compartments isolated from other cultural traits. When the Ifugaos cultivate rice, build houses, sell their lands; when they marry, give birth, raise children, celebrate feasts, or when they live their lives by the sacred traditions of their ancestors, they are practising their religion (Lambrecht, 1979).

Anthropologist used the concept of acculturation to describe a situation in which one of the societies in contact is much more powerful than the other was. Thus, acculturation can be seen as a process of extensive cultural borrowing in the context of superordinate-subordinate relations between societies (Ember \& Ember, 1999, pp. 307-308). The Spaniards, Americans, and Japanese people tried to propagate to the Ifugaos their culture. Both the Spaniards and the Japanese were not successful in their attempts to convert the Ifugaos with their religion and way of life. During the Spanish period, only a few Ifugaos were forced to be converted to Christianity because they wanted to recover their properties taken away by the Spanish officials. During the Japanese occupation, Ifugaos were again forced to bow to the Japanese government or else they will be motivated and tortured by the Japanese officials. Ifugaos did not like this kind of treatment. Therefore, others escaped and went to other places while others remained but fought for their independence. They did not embrace the Japanese or Spanish culture although they were taught in schools. Those acts were attempts to acculturate the Ifugaos, but they were not successful because the Ifugaos resisted and continued the way of life handed down to them by their ancestors (Lambrecht, 1979). 
However, under the American regime, the Ifugaos adopted acceptant acculturation receptivity to new socio-cultural forms. Americans implemented socio-cultural goals for which the Filipinos had already been striving in a more or less difficult way. We think that the most efficient way in which the Americans introduced the "Western" way of life to the Ifugaos was through education. They showed the Ifugaos a new way of life that would make their lives better. At the same time, the Americans introduced building of roads and trails that made it easier for them to travel from one place to another. Commerce was also abundant. The Americans instituted a political system where Ifugaos became leaders and experienced democracy (Andres, 2004; Lambrecht, 1979; Vergara, 1995).

American officials prohibited the practices of certain customs and tradition like headhunting, the boiling water method of setting disputes, etc. Gradually, the Ifugaos adopted these practices and had replaced some of their traditions and practices. Christianity was more effective in converting the Ifugaos during this period (Andres, 2004; Lambrecht, 1979; Vergara, 1995). The coming of the Congregation of the Immaculate Conception Missionaries (CICM) in Mountain Province in 1907 marked a new era in the propagation of the Catholic faith among them. The Belgian Fathers convinced many Ifugaos to be baptised during this period (Andres, 2004; Lambrecht, 1979).

When I asked Mrs Mildred of her religion, she told me she is a Catholic. Then, she would still tell stories when they practice some of their old traditions. "Binyag kami. Kahit Christian ako hindi ko naman tatalikuran. Always na kung may sakit or kung may ano dun sa bahay, talagang nagkaCañao kami." (We are baptised. Even if, I am a Christian I did not neglect those rituals. We always do it during sick, or any miserable things happened in our house, we practice the ritual of Cañao). They still believe in their ancestors and keep heirlooms handed down from one generation to generation. The Bulol or their rice god was very important for the Ifugaos that every family has its own bulol passed in the generations of the family. This woodcarving was still used during festivals and important occasions and rituals. However, some Ifugaos were trying to change their beliefs and traditions because of other religions that came to the place. As what Mrs Mildred said,

“... Yung mga sumusulpot na religion ngayon na mga Born Again, na sinasabi sa amin na dapat itapon nyo na yung mga bulol nyo, yung mga gamit nyo sa bahay na ginagamit sa rituals. 
Yun ang inaano ng mga Protestants, Born Again. Ngayon yung mga taga-dun sa amin talagang gini-get rid off... binebenta nila or sinusunog nila..."

(...Those are new forms of religion especially those Born Again, they teach us that we need to abandon our idols, those things in our house that are being used during rituals. Those are the things for Protestants and Born Again. Today, some of the Ifugaos in our area follow them to get rid off, they sell and burn it).

(Interview with Y. Mildred, 16 November 2007)

However, those who still believe in their traditions keep them. They also keep their old traditions by using their Ifugao cultural goods in their everyday living. "Pero meron namang iba na tinatago talaga nila kahit na Christian sila, tinatago pa rin nila ang mga gamit nila." (But few Christians preserve and use those idols until now). The hagabi, the Ifugao chair, was still used by Mrs. Mildred and other Ifugaos. It was one of the bestselling items in her store. The Ifugaos themselves usually made this furniture. This implied that she had wholly accepted the doctrine of Christianity since most of their relatives had been baptised. But in terms of concrete religious behavior, her activities were heavily oriented toward the observance of popular beliefs sanctioned by the community and not necessarily by the church. There is a blending of official Catholic Church doctrines and practices with local ways of thinking, believing and doing things.

At present, only the non-Christian Ifugaos still put themselves at the mercy of their duties. Most Ifugaos, especially the educated, the younger generation have freed themselves from this bondage and had embraced the Christian faith. However, most Ifugaos who still remember and have strong faith in their ancestral worship continue their traditions (Andres 2004).

The second type acculturation experienced by the Ifugaos was that subordinate society might acculturate to a dominant society due to indirect force. The dominated people may elect to adopt cultural elements from dominant society to survive in their changed world. Dominated people often have little choice but to change (Ember, 1999, pp. 307-308). I want to mention here the shifts in meanings of the Ifugao cultural goods into more economically valuable objects. They were obliged to give up many aspects of 
their traditional way of life. In order to survive, they had no choice but to adopt many of the dominant society's traits. Since Ifugaos were exposed to a more commercialised period nowadays, they must adapt and find ways on how to survive in their changed world. Before most of them relied on their environment for survival, they plant rice, root crops and vegetables and fruits in their farms or go to the forest to gather wild plants and animals. As what Mrs Mildred had described, they were industrious people and kept on working just to provide for the needs of the family, she said. When they become more in number, there was a scarcity of resources that cannot support their everyday needs anymore.

They need to earn a living to provide their needs and send their children to school. They had simple lifestyles, but they still struggle to maintain their kind of living. "Actually yung [pagka-carve] ang pinagkukunan nila ng pagkain. Kasi hindi naman yung rice terraces dun hindi sapat. Iilan lang ang may rice terraces dun." (Those woodcarvings are their source of food. Since not at all the times, working at the payoh or rice terraces is enough to support them. Many of them do not have their terrace). At this time, most Ifugaos work as farmers and woodcarvers. There were farmers who own farms in the terraces, but most of the people still go to the centre to buy rice and vegetables. The farms were not enough to feed all Ifugao families. They only harvest rice or goods once a year. Unlike the farms in the lowlands, that has wider fields, and harvesting can be done twice a year. Children at the age of seven already knew how to carve, usually simple ones, like ashtrays. Woodcarving was one of the typical industries in Ifugao. Through woodcarving, they were able to support the needs of the family. "Para sa kanila kaya sila nagma-mass produce para may pambili sila ng pagkain at the same time yun ang mabenta kase mura (For them, doing mass production of cultural goods, it can support their needs especially to buy food, at the same time it is easy to sold because of its cheaper price)," she said. Mrs Mildred was encouraged to put up a business of selling woodcarvings from Ifugao because they were used to it and it was patronised by both local and foreign tourists. She told me how the Ifugaos produce these products.

The Ifugaos get woods from the mountains, as far as reaching Isabela, Cagayan or anywhere where they can get good woods. They would cut the woods into pieces before bringing them down the mountain. When they reach their houses, they will start carving. After finishing the product, they would transport them to the centre and sell them to the local market at a minimum price. They do this in order to survive. Their prices were very low that 
sometimes it was not enough for the labour they did. At times when no one is willing to buy the product, they have no choice but to leave them in the market and come back until it was bought. That is the Banaue life. When they go home, they already bought rice for the family, enough for week consumption. They produce many products usually when there were orders. Like what Mrs Mildred was doing, she had a shop and contacted the other Ifugaos who would produce the products when there were orders. If the agreement was for a month, the production should be done in a month. The dealers would leave the payment to be sure that they would finish it. Their problem was before they finish the product, they have already used the money. Mrs Mildred would let them finish the production first before paying them so that they will not be able to use the money.

Mass produced goods were cheaper that anyone would be able to buy them than antique ones. It also helped the Ifugaos earn a living. However, because of the mass production of the Ifugao cultural goods, their traditional meanings and symbolisms gradually change. The Bulol now becomes an embellishment in the houses of the buyers who adore its beauty and its being unique. It became an object with an economic value that was part of earning a living for the Ifugaos. It had lost its religious and sacred value. Other Ifugao cultural goods also experienced the same problem. The new generation had not known the cultural goods old value for their ancestors, especially those educated ones who learn the new culture in their schools. The more educated they become, the more they move away from their customs and traditions.

\section{The WOW Philippines Experience}

The WOW Philippines is a project of the Department of Tourism (DOT) under the governance of Secretary Richard Gordon. It aims at promoting the different region in the country. With the supervision of the Philippine Tourism Authority (PTA), they utilised a part in Intramuros to put a clamshell where cultural products are sold. Around the area, they are booths selling various cultural products from Bicol, Baguio, Pampanga, and Capiz. During its height of flourishes, the place was active throughout the whole day. Bands played during the night, and many food stalls were present.

Going into a large-scale view of the shifts in meanings of the cultural goods of the natives in the Philippines, the WOW Philippines can be said as one of the important wheels in promoting these cultural goods. Mrs Mildred 
also happened to participate in the WOW Philippines. She came there during November in 2004. According to her, the events were successful the whole year round. There were different performances by different native groups every night that attracts tourists. The whole Intramuros was lively and full of visitors every night until 2 to $3 \mathrm{am}$. The business industry was good. The WOW Philippines had promoted tourism in Banaue, as well as other tourist destinations in the country.

From the mountains of Ifugao as a field of production, WOW Philippines is a field of reproduction. WOW Philippines contributed to the shifts in meanings of the cultural products through conversion. From cultural goods are transformed into economic capital. With their cultural knowledge, the natives used in order to make an objectified cultural capital. Because of this present industry, they see it as an opportunity to earn a living, to buy food. There is a contestation between values and their means of survival. As art scholar, I am not here to judge the Ifugao on doing something like that. We respect them.

Mrs Mildred preferred to have business there because she thought that it could promote their province's cultural products. Also with that, she also wanted to help in meeting the needs of the family especially for the education of her children, and basically for their survival.

\section{References}

Andres, T. Q. D. (2004). Understanding Ifugao values. Giraffe Books. Bourdieu, P. (1984). Distinction: A Social Critique of the Judgement of Taste. Cambridge, Massachusetts: Harvard University Press.

Chamber, E. (1989). Applied Anthropology: A Practical Guide. Prospect Heights, Illinois: Waveland.

Ember, C. \& Ember M. (1999). Cultural Anthropology. New Jersey: Prentice-Hall, Inc.

Emener, W. \& Darrow M. (1991). Career Explorations in Human Services. Springfield, Illinois: Charles C. Thomas.

Lambrecht, F. (1979). The Main Factors of Resistance to Culture Change in Ifugao Land in Acculturation in the Philippines: Essays on Changing Societies. Quezon City: New Day Publishers. 
Veneracion, J. et al. (2005). Kasaysayang Bayan: Sampung Aralin sa Kasaysayang Pilipino. Manila: ADHIKA ng Pilipinas, Inc. \& National Historical Institute.

Vergara, B. (1995). Displaying Filipinos. Quezon City: University of the Philippines Press. 